\title{
DONGKREK: AN ISLAMIC LITERATURE AND ARTFORM IN MADIUN EAST JAVA
}

\author{
Kundharu Saddhono and Winda Dwi Lestari \\ Universitas Sebelas Maret, Surakarta \\ email: kundharu_s@staff.uns.ac.id
}

\begin{abstract}
Dakwah refers to the spreading of Islam and its teachings through various means. Dongkrek, meanwhile, is a traditional art form with Islamic literary value that has been used as a medium for dakwah. This study seeks to describe and explore dongkrek as an art form with Islamic literary value and its use as a medium for dakwah in Madiun Regency. It is a qualitative study, which takes as its case study a dongkrek troupe from Madiun Regency. The main source of data for this study is the dongkrek performance itself; supporting data has been collected from texts and informants. Data collection involved observations, library research, and in-depth interviews with informants. For this study, data analysis was conducted using content analysis and interactive analysis. This study finds that dongkrek is an Islamic literary art form believed to have been created by R. Bei Lo Prawirodipuro in 1910. It may be considered an Islamic art form as the lyrics used in performances convey Islamic teachings; it is through these lyrics that Islamic values are conveyed to audiences as a form of dakwah. It is shown that dakwah and dongkrek are complementary, ensuring both the innovativeness of dakwah and the survival of dongkrek. It may thus be said that dongkrek is a medium of both performance and guidance.
\end{abstract}

Keywords: dakwah media, dongkrek, tradition, traditional performance art

\section{DONGKREK: SEBUAH SASTRA ISLAM DAN PERTUNJUKAN SENI DI MADIUN JAWA TIMUR}

\begin{abstract}
Abstrak
Dakwah adalah cara menyebarkan agama Islam dengan metode yang beragam. Dongkreng adalah salah satu bentuk kesenian tradisional yang dapat digunakan sebagai media dakwah. Penelitian ini memiliki tujuan untuk menjelaskan dan mendeskripsikan kesenian dongkrek yang digunakan sebagai media dakwah di Kabupaten Madiun. Penelitian berbentuk penelitian kualitatif dengan pendekatan studi kasus. Studi kasus dilakukan pada kelompok kesenian dongkrek yang ada di Kabupaten Madiun. Sumber data utama dalam penelitian ini adalah bentuk pementasan dongkrek. Sumber data pendukung adalah teks dan informan. Teknik pengumpulan data dilakukan dengan observasi, studi pustaka, dan wawancara mendalam dengan informan. Teknik analisis data dalam penelitian ini menggunakan content analysis dan analisis interaktif. Dari hasil penelitian ditemukan bahwa kesenian dongkrek termasuk dalam sastra Islam yang diciptakan oleh
\end{abstract}


R. Bei Lo Prawirodipuro tahun 1910. Disebut kesenian sastra Islam karena dalam kesenian dongkrek terdapat lirik lagu yang memuat tentang ajaran agama Islam. Kesenian dongkrek digunakan sebagai media dakwah dengan mengajarkan syi'ar kepada masyarakat melalui pementasan seni dan budaya. Hal ini seperti yang dilakukan oleh walisongo. Hubungan antara dakwah dan dongkrek adalah saling menguntungkan yaitu pembaruan dalam bidang dakwah serta pelesarian dalam bidang budaya. Dapat dikatakan dongkrek adalah sebagai media tontonan dan tuntunan.

Kata kunci: media dakwah, dongkrek, tradisi, seni pertunjukan tradisional

\section{INTRODUCTION}

Dakwah may be understood as a 'call', 'invocation', or 'invitation'. Conceptually, dakwah can be understood as a process of inviting or mobilizing people to do good (Siddiq, 2005:77More specifically, dakwah is understood as a call for people to live in accordance with the substance of Islam: amar ma'ruf nahi munkar (Enjoining good and forbidding wrong). Dakwah and Islam, thus, are intertwined, and it may be said that progression and regression in dakwah stems from Muslims own dakwah activities (Arifin \& Muhlis, 2018:69). Muslims are expected to spread the teachings of Islam, thereby ensuring that its teachings and their guidance are disseminated. Yahya (2007:224) has shown that dakwah strategies are diverse, and that art and culture have been two important elements that have optimized dakwah activities and results.

Dakwah is a systematic process, involving a da'i (subject), maadah (material), thoriqoh (method), washilah (medium), and mad'u (object) to attain its maqashid (goal). In its means and methods, dakwah should be wise. As such, among the diverse approaches to dakwah is the cultural approach, which was used (for example) by the Wali (saints) who spread Islam to Java using a syncretic approach that accommodated the socio-cultural conditions of the island's people (Sofwan et al, 2004: 5). Although the Javanese were predominantly Hindu-Buddhist, the Islamicization process was peaceful and without conflict. Dakwah, thus, can be understood as functioning to transform Islam from a teaching (doctrine) into a social reality with a worldview rooted in the Qur'an and the Sunnah (Bachtiar, 2013:158).

The Wal's approach to dakwah remains influential even today. For example, the dakwah activities of $d a^{\prime} i$ in East Java continue to regularly employ a socio-cultural approach. In western East Java, more specifically in Mejayan Village, Madiun Regency, da'i use an artform called dongkrek for their dakwah activities. Dongkrek, a type of narrative performance art, has existed as part of local culture for generations. It is attributed to the late R. Bei Lo Prawirodipuro, who served as the palang-an official responsible for four or five village chiefs and directly accountable to a wedana-of Mejayan (Caruban).

As part of local culture in Mejayan, dongkrek is understood as having considerable educational value. Over time, it 
has evolved as a medium for dakwah; as such, it can be seen that local culture has specific value in dakwah activities, as it can help ensure that dakwah are properly targeted and optimally ensure balance and social progress (Haryono, 2018). Local culture offers unique patterns for conveying dakwah messages. This has been noted, for example, in discussion of tasawuf (the art of self-purification) by $\mathrm{Mu}-$ lyati (2006), as well as in examinations of the use of local cultural perspectives in dakwah by Sofwan (2004) and Hasan (2013). It presents a medium that can be used to facilitate the dakwah process.

From a local cultural perspective, it has been argued that dakwah can significantly contribute to the preservation and appreciation of local culture. Wekke and Sari (2014:171) have examined the practice of dakwah from a local culture perspective, showing that dakwah can provide a source of inspiration that drives the preservation and development of 1ocal culture despite global influences. A similar perspective has been used by Jabrohim (2012:58) in his study of media-in this case, srundul - that can be used to spread dakwah messages. Van Dijk (1998) - in his study of the values and contents of dakwah-applied a different perspective but nonetheless considered the media used for and values contained within dakwah. Based on this review of the literature, the connection between dakwah and local culture (such as dongkrek) may be understood as close, reciprocal, synergic, and cohesive. Each supports the other. Local culture supports the continued practice and success of $d a$ $k w a h$, while dakwah promotes the survival and preservation of local culture.
This article will explore dongkrek and its use as a medium for dakwah in Madiun within the constellation of Islamic literature and art. As a form of performance art, dongkrek has strong literary value; similarly, given its use as a medium for dakwah, it may be seen to have a significant Islamic character.

\section{METHOD}

This research is a library study, with data collected through a review of the literature and the 'world of the text' being the main object of analysis. As such, the researcher will systematically, factually, and describe the facts and characteristics of the research object. Using a specific conceptual (theoretical) framework, certain concepts will be applied to produce variables and indicators. This study will depict the reality as it exists now, without exploring the connections between variables (Kriyantono, 2006:48).

This study focuses on the communication strategies applied by da'i in using dongkrek as a medium for dakwah. Dongkrek is an indigenous artform from Mejayan Village, which has become a medium for dakwah. Data on this research object and related concepts will be collected, analyzed, and classified, before a conclusion is drawn. The analytical model used for this study is the qualitative model. Sutopo (1998: 23) stated that qualitative analysis involves the analysis of data without using specific categories or connecting them.

\section{RESULTS AND DISCUSSION Result}

From research conducted by the writer, known and find that dongkrek arts as 
a one of Islamic art and literature which have Islamic religious shades. This is reflected from the lyric and instrument which used in dongkrek performing arts. Furthermore, lyric and instrument on dongkrek arts will be discuss in this parts.

\section{Dongkrek: an Islamic Art and Litera- ture}

Dongkrek is held to have been created by the late R. Bei Lo Prawirodipuro while he was serving as the palang of Mejayan (Caruban). During the colonial era, a palang was an individual responsible for 4-5 village chiefs, or lurah; as the "head lurah" (hoofd lurah), the palang was directly accountable to the wedana. R. Bei Lo Prawirodipuro was the last palang of the region, serving until his death c. $1915 / 1916$. At the time, the office of palang had already been disbanded; however, R. Bei Lo Prawirodipuro received special treatment. This is attributed to his personal leadership abilities and authority, which led to him being respected as a decision-maker.

It is thought that dongkrek was first performed c. 1910, and several sources indicate that after R. Bei Lo Prawirodipuro created dongkrek other artforms began emerging. Dongkrek grew rapidly, becoming the most popular artform in the contemporary community. However, this dominance did not last long. Over time, its popularity began to dwindle, and in time even its name was forgotten-especially by persons from outside the $\mathrm{Ca}$ ruban area.

The reason for dongkrek's loss of popularity has not be ascertained. It is possible that the death of its creator, known as a man of great wisdom and in- fluence, contributed to this. With the death of Prawirodipuro, dongkrek may have not only lost its creator, but also the only person who could guide its development. It is also possible that the static nature of dongkrek led to audiences becoming bored, seeking alternative artforms from Central Java, some of which remain common in Caruban and Madiun (Dinas Pendidikan dan Kebudayaan Kabupaten Madiun, 2011: 4-6). Dongkrek became popular at a time when Mejayan was afflicted by an epidemic; people would fall ill in the morning and be dead by sundown. As a leader, Prawirodipuro decided to seek a means of ending the disease that was plaguing his people. After lengthy contemplation and meditation in the mountains south of Caruban, he received a revelation: he would create a dance or performance art that could stave off disaster.

According to this revelation, a group of spirits or gendruwo had attacked Caruban, and thus they could be driven away by leading them outside of Caruban. As such, he created an artform that depicted the eviction of the spirits that were causing the epidemic. The artform experienced its glory days between 1867 and 1902; afterwards, its popularity ebbed and flowed as Indonesia's political conditions shifted.

When Java was under Dutch rule, the colonial government forbade the performance of dongkrek. It feared that, were dongkrek to be allowed to develop further, it could be used as a medium for gathering people in opposition to colonial rule. When the Indonesian Communist Party (PKI) seized control of Madiun, the artform became viewed as having 
been developed by the Party to deceive the common people. It can thus be seen that dongkrek's development has been influenced significantly by the political situation. In 1973, dongkrek was resurrected by the Office of Education and Culture, Madiun, in conjunction with the East Java government.

The story of dongkrek's invention can also be tracked through a song in gambuh verse. In Javanese literature, gambuh are considered part of the macapat song tradition. In this tradition, verses are known as gatra (Saddhono \& Pramestuti, 2018; Sujarwoko, 2014), and each gatra has specific syllables (guru wilangan) and end-of- line rhymes (guru lagu). The word macapat is Javanese. It has been read as an abbreviation of two words, maca papat-papat 'read four-by-four'; this reflects how macapat are read in groups of four syllables. However, this is just one of many interpretations of the word. Many works of classical Javanese literature were written during the Mataram era, and most of these used in macapat form; only few were written in prose (Mardikantoro, 2016: 271). Examples of Javanese literary works written as macapat include Serat Wedhatama, Serat Wulangreh, and Serat Kalatidha. The verses of the dongkrek macapat may be seen below.

Table. 1 The Lyric of Dongkrek Macapat

\begin{tabular}{ll}
\hline Javanese & English \\
\hline Keparenga amatur & Let [us] speak \\
Sekar gambuh amurwani atur & the song of gambuh opening \\
Seni dongkrek angirta dongkrek kang asli & the original art of dongkrek \\
Ngleluri budaya luhung & preserving the great culture \\
Ciptane leluhur kita & created by our ancestors \\
Semangke kang cinatur & we will tell \\
Riwayat dongkrek engkang asli & the true history of dongkrek \\
Asal saking Dusun Mejayan kang asli & coming from Mejayan Village \\
Palang kalenggahanipun & Palang, specifically \\
Priya luhur kang yasa & the honored man who created it \\
Jamane kang kapungkur & in the past \\
Duk semana Mejayan kang dusun & in Mejayan Village \\
Katrajang ing pagablug akeh pepati & suffering from disaster, many dead \\
Tambah-tambah polah ipun & many confused \\
Kawula ngudi usada & seeking the medicine \\
Berkah kang Maha Agung & the blessings of the Almighty \\
Eyang Palang hang sakti kalangkung & the mystic Eyang Palang \\
Metu brata angenta dongkrek mauwarni & mediated and found dongkrek \\
Kinarya mbrasta pageblug & chased away disaster \\
Sirna tapis tanpa sisa & gone without a trace \\
Suka sukur yang Agung & praising the Almighty \\
Para kawula bingah kalangkung & the residents rejoiced \\
Eyang Palang aparing dhawuh sayekti & Eyang Palang said \\
Istinen budaya luhung & preserve this grand culture \\
Nirkala suka raharja & for salvation \\
\hline SK Desa No $/$ D & \\
\hline
\end{tabular}

(SK Desa No 2/DK/4/414. 107. 07/0/2003) 
According to a book written by the Office of Education and Culture, Madiun, the name dongkrek is derived from onomatopoeia of the two instruments used in performances: bedug (drums) and korek (a kind of percussion instrument). Drums produced the sound dhung, while korek produced the sound krek; as such, played alternatively the instruments produced the sounds dhungkrek-dhung-krek. It is from this sound that the name dongkrek was taken.

Dongkrek performances involve more than these two instruments. Nonetheless, drums and korek remain essential and dominant. They are essential as they are required for performances, and they are dominant because they have a prominent and important role. It is these two instruments that have continued to characterize dongkrek; this is particularly true for korek, a unique instrument that cannot be found in other artforms.

\section{The Meaning of Gamelan in Dongkrek}

Dongkrek is a form of performance art. In its performance, it conveys specific messages, including amar ma'ruf nahi munkar (that evil will be vanquished by good). Dongkrek performances open with the sounding of gamelan (a set of percussion instruments used in Javanese performances), including kenthongan, kenong, bedug, korek, gong beri, and gong gedhe; each of these have their own meanings.

The kenthongan is understood as a symbol of calling people together for a performance, "Saiyeg saeka praya". During dongkrek performances, usually three kenthongan are used. These instruments are intended to call people together when they hear the sound of the titir (an alternative name for the kenthongan).

The kenong is understood as a symbol of silence, contemplation, and devotion to the Almighty. Usually, dongkrek performances involve one kenong, which is intended to create a sense of calm and peace.

The bedug is used as a symbol of the Palang's abilities as a leader, "ora tedas tapa paluning pande" (dug deng). In dongkrek performances, one bedug is usually used. This is intended to symbolize the Oneness of God; no matter how strong or skilled an individual is, he or she cannot become stronger than God.

The korek is recognized as symbolizing the cleansing of disaster and unseen dangers. In dongkrek performances, three korek are usually used. These instruments are intended to ensure that all spirits and other supernatural beings do not disturb the human residents of the area.

The gong beri is understood to mean "berbudi wibowo laksono, rawe-rawe rantas malang-malang putung", or "working together to eradicate illness". The gong beri is round, made of a thin sheet of bronze, and played from a hung position.

The gong gedhe is used to represent the end of something, such as a successful endeavor, reflecting the saying man jadda wajada 'whosoever works with dedication will succeed'. In dongkrek performances, usually one gong gedhe is used, indicating the end of an activity.

The gamelan is played, and then a fragment is performed. The characters include Eyang Palang as well as djinns/ spirits wearing masks (red, black, green, yellow, and white). These djinns are 
shown disturbing the people of the village, leading to Eyang Palang asking the Creator for a solution. With God's power, the epidemic (pagebluk) in Mejayan was eradicated.

\section{Discussion}

\section{Dongkrek as Dakwah Media}

The objects of dakwah are diverse, as are the challenges faced by Muslims in different places and times. Recognizing this diversity, the strategies used by da' $i$ must vary as well. Likewise, the cultures of dakwah objects are diverse (Saddhono \& Kurniawan, 2017). The word dakwah is often used directly within the verses of the Qur'an, which Muslims believe is written in God's words as revealed to the Prophet Muhammad. This underscores the importance of dakwah in Muslim life. It is thus no surprise that M. Iqbal, a reformist from Pakistan, once said: "one of the most influential things in my life was my father's advice: son, read the Qur'an as if it were revealed unto you" (Basit, 2013:26).

Dakwah has the goal of inviting or influencing people to behave in accordance with Islamic teachings and law. To achieve this goal, audiences must be properly targeted; as such, media is needed. Two types of dakwah media are known. First, dakwah through oral media. Such dakwah is common among Muslims, as it involves direct interactions between the da'i and mad'u such as through sermons, advice, speeches, lectures, discussions (dialog), and seminars. The Qur'an includes several mentions of oral literature, including in Q.S. Al-A'raf: 158. " Say, [O Muhammad], "O mankind, indeed I am the Messenger of Allah to you all, [from Him] to whom belongs the dominion of the heavens and the earth. There is no deity except Him; He gives life and causes death." So believe in Allah and His Messenger, the unlettered prophet, who believes in Allah and His words, and follow him that you may be guided." Dakwah through unidirectional sermons are most common among $\mathrm{Mu}-$ slims today; as such, future sermons should seek to create interactive dialog (i.e. question-and-answer sessions), also known as dakwah bi-al-mujadalah. Such an approach to dakwah involves the rational exchange of thoughts between parties with different backgrounds to find the truest way to approach God (Aripudin, 2012:3). This is intended to provide audiences with the opportunity to voice their opinions and ask questions about topics of which their understanding is limited.

Second is dakwah through written media, including books, magazines, newspapers, bulletins, banners, posters, announcements, etc. In the Qur'an, there is no direct mention of the use of written media for dakwah purposes. However, its use may be inferred from one of the verses of the Qur'an, namely Verse 1 of Sura Al-Qalam. This verse, "Nun. By the pen and what they inscribe," implies the importance of the written word in dakwah. The Prophet Muhammad also provided an example when he told his companions to write letters to the non-Muslim leaders of the world-including Khosrow II in Persia (Iran), King Armah (also known as Najashi) in Abyssinia (Ethiopia), Hercules in Byzantium, and Maukukis in Egypt - and urge them to embrace the teachings of Islam. The letters included, 
for example, statements such as "I encourage you to welcome the call of God, embrace Islam so that you may be saved". This indicates that the dakwah of the Prophet, aside from being conducted through oral media, also involved written media. Similarly, an ulama (Islamic scholar) may conduct dakwah through such means as teaching, writing, and counselling. A rich man, meanwhile, can use his wealth to conduct dakwah by helping the financially destitute, tending to orphans, and funding the education of destitute Muslims. Persons in power, meanwhile, can conduct dakwah by using their authority to fulfil the needs (food, shelter, clothing, etc.) and security of their people (Ahmad, 2013:75-89).

In essence, dakwah is an actualization of faith in human social life (Shiddiq, 2013: 8). In an intercultural context, dakwah may be understood as a means of influencing how people think, feel, and behave at both an individual and socio-cultural level, with the intent of ensuring that Islamic teachings are embraced and practiced in all aspects of life (Razi, 2007:34). Dakwah involves multiple aspects: da'i, mad'u, method, material, and media; similarly, communication involves the aspects of communicator, communicant, message, media, and effect. Such a finding has also been made by Farida (2016:301). As such, dakwah resembles communication, with the main difference being that the "effect" element is not listed as part of dakwah. However, all forms of communication-including dakwah-will have a certain effect. Da'i are expected to be able to convey their materials clearly to mad'u, and are perceived as having been successful if the da'i are capable of influencing their understandings. In communication sciences, this is known as effective communications. To ensure that this desired effect occurs, a da'i must understand the condition of the mad'u. As such, intercultural communication is important; by understanding the culture of the mad'u, the da'i can properly complete his or her duties. As shown by Akhyar (2014) in his exploration of rhetoric and dakwah, intercultural communication cannot be separated from the rhetorical context in which it is implicitly or explicitly integrated.

One common approach to dakwah is known as dakwah bil hikmah, which involves a wise and measured approach that leads to the object of dakwah (the mad'u) embracing the message of their own volition, without feeling forced or pressured to do so. Such an approach is necessary in intercultural dakwah, wherein the message of dakwah intersects with the socio-cultural reality of the mad'u. As a result, dakwah must be understood as one variable in social life, and must thus be understood in terms of its ability to effect social change and create a new, ideal society (khoiru ummah). Arifani (2008) explains the synergy and strategy of dakwah from a cultural perspective, writing that dakwah is a form of social education, and thus has goals similar to those of national education. In the case of dakwah, however, religious morals are central.

Intercultural dakwah is a process that considers the cultural differences between the da'i (subject of dakwah) and mad'u (object of dakwah), as well as the diverse causes of problems in intercultural com- 
munications, to ensure that its message is conveyed effectively and peacefully (Setyawan \& Saddhono, 2018:67). It invites individuals to consider how they can convey Islamic teachings and behaviors in accordance with the cultural concepts in society. At its essence is the question of how, in dakwah, one can recognize the culture of the mad'u and adapt one's material, method, medium, and strategies to said cultural conditions. Don and Yunus (2009:168) link dakwah with alternative communications, noting that all people, places, and environments have their own socio-cultural conditions, and that dakwah-as a process of spreading the teachings and values of Islam within a specific society-must unendingly interact with local culture. This understanding of dakwah prioritizes sympathy, wisdom, and humanity (Pimay, 2005:45).

A review of previous research and studies, including by Sunyoto (2010:133), indicates that the influence of literature and art is closely related to the medium used. This holds true for dakwah as well, including dakwah through dongkrek and other cultural performances (as done by the Wali). Javanese traditions such as karawitan had inspired Wali such as Sunan Kalijaga to embrace the use of local culture and performances such as gamelan. When residents of rural areas heard the sound of gamelan, they would seek its source in search of a performance. Before watching the performance, they would be required to conduct ablution and recite the Shahada; as such, many people embraced Islam. As the gamelan played, audiences were introduced to the teachings of Islam (Purwadi, 2007: 16). In their dakwah, the Wali emphasized ten points:

First, sugih tanpa bandha; dakwah does not depend on one's material possessions, but rather on mental and spiritual serenity. Second, nglurug tanpa bala; the success of dakwah is determined not by the number of participants, but rather the spread of God's word. Third, menang tanpa ngasorake; in dakwah, a da'i may not belittle his or her mad'u, as all humans are equal before God. Fourth, mulya tanpa punggawa; one is only glorified by one's faith and charitable deeds, not by the number of one's followers. Fifth, mletik tanpa sutang; one must conduct dakwah throughout all of the natural world, believing that God will provide. Sixth, mabur tanpa lar; one must conduct dakwah without any personal interests. Seventh, digdaya tanpa aji-aji; even when a da' $i$ is mentally or physically assaulted, he or she must stand strong and continue preaching. Eighth, menang tanpa tanding; one must conduct dakwah by using wisdom, proper etiquette, and providing good advice, rather than coercion or violence. Ninth, kuncara tanpa wara-wara; a da'i must meet the mad'u regularly, without publication. Tenth, kalimasada senjatane; one must conduct dakwah in many places to ensure the recognition of the kalimasada (shahada).

In the time of the Wali, da'i did not conduct dakwah by delivering speeches or sermons in front of the general public (as common today), but rather through limited or even face-to-face halaqahhalaqah (meetings). Teachings spread through word-of-mouth, and as the number of mad'u increased dakwah was conducted in institutions of education known as madrasa or pondok (Mulyati, 2006:11). 
The use of traditional artforms as dakwah media was, and remains, widely appreciated by Javanese society. This can be seen from the number of da'i who have continued to embrace a cultural approach to dakwah in both urban and rural settings; take, for example, Emha Ainun Najib (better known as Cak Nun) who used the concept of Kiai Kanjeng, as well as music dominated by gamelan. Similarly, Pahlevi (2016) has explored cultural approaches to dakwah. As such, it is not surprising if dongkrek has also become a medium for dakwah, as the artform is not only a complete performance experience but is used to convey Javanese and Islamic teachings. Similarly, the people involved have the necessary ability to translate the messages they receive, as found by Enjang (2011: 471).

The use of art and culture as media for dakwah cannot be separated from the Nahdlatul Ulama and its understanding of Islam that emphasizes ahlusunnah wal jama'ah ("the people of the sunnah and the community") as a means of ensuring justice and prosperity. To achieve this goal, one must integrate education, learning, and culture to produce a means of cultural education and development that reflects the teachings of Islam and produce Muslims who are devout, cultured, knowledgeable, and skilled, and therefore beneficial to their religion, people, and state (Razi, 2011: 166).

Dakwah activities tend to be positively received by communities when they involve information and communication technologies. The successful dakwah activities by individuals such as Yusuf Mansur, Aa Gym, and Ary Ginanjar, as well as organizations such as Dompet
Dhuafa, have used information and communication technologies such as televisions, cellular phones, the internet, newspapers, etc. (Basit, 2013: 78). As such, it cannot be denied that da'i must adapt to the changing times while remaining true to Islamic teachings.

A value is a specific understanding or attitude used in appreciating something. As argued by Nangim et al (2013), the concept of value is central to dakwah. Humans believe that something is of value when they consider it necessary or appreciate it. They evaluate the world and their surroundings in order to fulfil their needs, obtain benefits, and find satisfaction.

At the core of value education is a cultural process that seeks to continuously increase the dignity of humanity. It is a process of humanizing humankind, of teaching humanity. It is also an activity through which specific values are embedded, including religious values (religious education), moral values (citizenship education), and aesthetic values (art education).

Values conveyed in dongkrek performances include cultural values, educational values, moral values, leadership values, heroism values, and aesthetic values. This can be seen from the musical instruments, masks, and costumes used in the performance, all of which have symbolic meaning; such a has been explored previously by Suresman and Suryana (2015) in their discussion of Islamic music as a means of dakwah. One moral value taught by dongkrek include that good will always vanquish evil.

According to Koentjaraningrat (1990:90), among the most abstract yet 
important elements of tradition is cultural value. Cultural values are concepts of what is valuable or important in social life, and as such serve people with direction in their social lives (Sugiarti, 2019). In this context, it is important to recognize diversity; as argued by Huriyudin (2015: 59), diversity in society affects the practice of dakwah.

As a ritual for warding off pestilence and disaster, dongkrek includes several elements: (1) the paraga 'actors' deemed capable of completing the ritual are brought to the pendopo (villa) to receive instruction from Eyang Palang regarding the physical and spiritual preparations necessary; (2) the paraga begin to lelampah 'act' in accordance with the instructions they receive; (3) on the night of the ritual (which, following the Javanese calendar, falls on a legi Friday), all actors gather for a ceremony (barokahan) to ask God's blessings; and (4) in the middle of the night, the performance begins, accompanied with prayer and worship. At this time, the ritual begins with the departure of a procession from the pendopo. This procession goes through Mejayan village until the early morning. During this ritual, all of the dongkrek performers-particularly those portraying gendruwo (spirits) must remain nude; all performers are male.

Certain media are used for this ritual: (1) bamboo torches; (2) incense, which is burned while prayers are recited; (3) heirlooms of the palang, which are carried by a heir; (4) certain types of food as well as a takhir (a shaped vessel made of banana leaves) filled with rice porridge; these are left at pre-determined places, such as intersections; (5) gendruwon and other equipment; and (6) elders with gambengamben (great knowledge). This procession only travels once; afterwards, some elements travel throughout the village until the epidemic abates.

Leadership values conveyed by dongkrek include what is good and true. It urges leaders to teach their followers and their people how to behave kindly, honestly, justly, and wisely. These leadership values are conveyed by the character of Eyang Palang, who leads the people of Mejayan wisely and responsibly.

The concept of heroism is generally linked with courage and sacrifice, as well as defending the truth (Supratno, 2010:380). In this article, heroism is understood as involving the courage to protect the truth, as conveyed through dongkrek. This heroism is presented in dongkrek through the character of Eyang Palang, who had the courage to challenge the buto/gendruwo and save his people from disease. Similarly, Pujiyanto (2012) has explored the use of media in dakwah; in such cases, medium and message unite to ensure understanding. Similarly, Abdullah et al (2012:33) have shown that the presentation of dakwah messages requires appropriate strategies.

Aesthetics may be understood as the philosophy of beauty, both natural and human-made. This understanding first emerged in the West, more specifically in Ancient Greece, through scholars such as Plato, Aristotle, and Socrates (Sumardjo, 2000:33). In this study, aesthetic value is understood as a beauty that can be enjoyed. In dongkrek, aesthetic value can be seen and heard through the musical instruments, masks, costumes, and dances involved. This is supported by Puteh 
(2006), who notes that art is part of the message of dakwah.

\section{CONCLUSION}

Dakwah is a means of spreading Islamic teachings. Through dakwah, a da'i introduces Islam and its teachings to others. Various approaches to dakwah have emerged in society, including dakwah through mass media, electronics, and gadgets. Nonetheless, face-to-face dakwah remains common. Meanwhile, intercultural dakwah is dakwah that recognizes the cultural differences of the da'i (subject) and mad'u (object) and seeks to bridge these differences to ensure the message is received and peace is maintained. Intercultural dakwah, thus, involves the teaching of Islam and Islamic behaviors in accordance with the cultural context of the audience. Culture, thus, can be a medium, method, tool, and strategy. All people, places, and societies have their own specific socio-cultural differences, place, and society. Dakwah - as a process of spreading the teachings and values of Islam within a specific society-must unendingly interact with local culture. This understanding of dakwah prioritizes sympathy, wisdom, and humanity

In the current information era, dakwah has continued to innovate. This includes, for example, through the use of dongkrek and its strongly Islamic messages. Dongkrek is a traditional performance art that has developed in and around Mejayan Village. Its use in dakwah is an adaptation of the methods used by the Wali. The connection between dakwah and dongkrek is mutually beneficial, promoting innovative dakwah as well as cultural conservation.

\section{ACKNOWLEDGEMENTS}

The writer would like to express his gratitude to the Postgraduate School and the Center for Research and Public Service of Universitas Sebelas Maret for supporting this study.

\section{REFERENCES}

Abdullah, A. M., Tibek, S. R. H., Mujani, W. K., Dakir, J., \& Yusuf, K. (2012). "Amalan Barzanji, Adakah Ia Selaras Dengan Ajaran Islam?" International Journal of West Asian Studies, 4(2), 23-35. http://ejournal. ukm.my/ijwas/article/view/14563.

Ahmad, A. A. (2013). Dakwah, Seni, dan Teknologi Pembelajaran. Jurnal Dakwah Tabligh, 14(1), 75-89. https://doi.org/10.24252/jdt. v14i1.315) diakses di http://journal. uin-alauddin.ac.id/index.php/ tabligh/article/view/315.

Akhyar, T. (2014). Dakwah dan Perubahan Sosial. Wardah: Jurnal Dakwah dan Kemasyarakatan, 15(2), 113-119. (http://repo.iain-padangsidimpuan. ac.id/202/1/Ali\%20Amran1.pdf.

Arifani, M. A. (2008). Eksistensi Budaya Lokal sebagai Model Pengembangan Dakwah: Pendekatan Sosiologis. Jurnal Ilmu Dakwah, 4(12), 193214. https://doi.org/10.15575/idajhs.v4i12.393.

Arifin, M. T. \& Muhlis, A. (2018). Pesan Dakwah dalam Album Ketika Hati Bicara karya Ebith Beat *A. Tabligh: Jurnal Komunikasi dan Penyiaran Islam, 3(1), 68-90. DOI: 10.15575/ TABLIGH.V3I1.32. http://jurnal. fdk.uinsgd.ac.id/index.php/ tabligh/article/view/32. 
Aripudin, A. (2011). Pengembangan Metode Dakwah: Respons Da'i terhadap Dinamika Kehidupan di Kaki Ceremai. Jakarta: PT Raja Grafindo Persada.

Bachtiar, A. (2013). Dakwah Kolaboratif: Model Alternatif Komunikasi Islam Kontemporer. Jurnal Komunikasi Islam, 3(1), 152-168. http://dx.doi. org/10.15642/jki.2013.3.1.\%25p). http://jki.uinsby.ac.id/index.php/ $\mathrm{jki} /$ article/view/19.

Basit, A. (2013). Dakwah Cerdas Era Modern. Jurnal Komunikasi Islam. 3(1), 76-94.http://dx.doi . org/10.15642/jki.2013.3.1.\%25p.

Don, A. G., \& Yunus, A. R. M. (2009). Dakwah Kepada Orang Asli melalui Seni Hiburan Alternatif di Malaysia: Model Latihan Amali Dakwah (LAD). Al-Hikmah, 1, 3-12. http:// spaj.ukm.my/jalhikmah/index. php/jalhikmah/article/view/42.

Enjang, A. S. (2011). Pengembangan Masyarakat Islam dalam Sistem Dakwah. Ilmu Dakwah: Academic Journal for Homiletic Studies, 5(2), 469-482. https://doi.org/10.15575/ idajhs.v5i18.375.http://journal. uinsgd.ac.id/index.php/idajhs/ article/view/375

Farida, U. (2016). Islamisasi di Demak Abad XV M: Kolaborasi Dinamis Ulama-Umara dalam Dakwah Islam di Demak. At-Tabsyir: Jurnal Komunikasi Penyiaran Islam, 3(2), 299 318. 10.21043/at-tabsyir.v3i2.1649. http://journal.stainkudus.ac.id/index.php/komunikasi/article/ view/1649

Haryono, A. (2018). Strategi Komunikasi dalam Proses Bhâkalan Etnik Madura di Daerah Tapal Kuda. Jurnal
Litera, 17(3), 259-278. https://doi. org/10.21831/1tr.v17i3.18070. diakses di https://journal.uny.ac.id/index.php/litera/article/view/18070.

Hasan, R. (2013). Seni Seudati: Media Edukasi Sufistik dalam Mengembangkan Nilai Sosio-Religius Masyarakat Aceh. Al-Tahrir, 13(1), 151170. https://doi.org/10.21154/altahrir.v13i1.11.http://jurnal.iainponorogo.ac.id/index.php/tahrir/ article/view/11.

Huriyudin, H. (2015). Ekspresi Seni Budaya Islam di Tengah Kemajemukan Masyarakat Banten. Jurnal Lektur Keagamaan, 12(1), 57-296. (http:// dx.doi.org/10.31291/j1k.v12i1.36) diakses di https://jurnallekturkeagamaan.kemenag.go.id/index.php/ lektur/article/view/36

Jabrohim. (2012). Pemanfaatan Srundul sebagai Salah Satu Alternatif Pendukung Dakwah Islam melalui Karya Seni. Tsaqafa: Jurnal Kajian Seni Budaya Islam, 1(1), 55-73. http://digilib.fib.ugm.ac.id/book/ detail/5697.

Koentjaraningrat. (1990). Kebudayaan mentalis dan pembangunan. Jakarta: Gramedia.

Kriyantono, R. (2006). Teknik Praktis Riset Komunikasi. Prenada Media Group: Jakarta.

Mardikantoro, H. B. (2016). Pemertahanan Bahasa Jawa dalam Pertunjukan Kesenian Tradisonal di Jawa Tengah. Jurnal Litera, 15(2), 269-280. https://doi.org/10.21831/1tr. v15i2.11828. https://journal.uny. ac.id/index.php/litera/article/ view/11828.

Mulyati, S. (2006). Tasawuf Nusantara: 
Rangkaian Mutiara Sufi Terkemuka. Jakarta: Kencana Prenada Grup.

Nangim, C., Islam, F. A., \& Islam, P. K. P. (2013). Nilai Dakwah dalam Serat Wulangreh Karya Pakubuwana IV: Pada Tembang Gambuh dan Asmarandana. Komunikasi Penyiaran Islam, 8(8), 16-30. http://thesis.umy.ac. id/datapublik/t25356.pdf.

Pahlevi, R. (2016). Dakwah Kultural Bayt Al-Quran Al-Akbar Ukiran Kayu Khas Melayu Palembang. Intizar, 22(1), 173-197.https://doi. org/10.19109/intizar.v22i1.548. http://jurnal.radenfatah.ac.id/index.php/intizar/article/view/548

Pimay, W. A. (2005). Paradigma Dakwah Humanis: Strategi dan Metode Dakwah Saefudin Zuhri. Semarang: Rasail.

Pujiyanto, T. (2012). The Role of Sragen Walisongo Tambourine Art in K.H. Ma'ruf Islamuddin's Da'wah Strategy. Candi, 4(2). 1-16. https://eprints. uns.ac.id/11156/.

Purwadi. (2007). Dakwah Sunan Kalijaga: Penyebaran Agama Islam di Jawa Berbasis Kultural. Yogyakarta: Pustaka Pelajar.

Puteh, A. (2006). Prosiding Seminar Serantau Dakwah dan Kesenian: Tema, Seni Membentuk Nilai Murni. Center for Dakwah and Leadership Studies, Faculty of Islamic Studies, Universiti Kebangsaan Malaysia.

Razi, F. (2011). NU dan Kontinuitas Dakwah Kultural. Jurnal Komunikasi Islam, 3(1)161-171.(http://dx.doi. org/10.15642/jki.2011.1.2.161\%20 -\%20171) diakses di http://jki.uinsby. ac.id/index.php/jki/article/view/86

Saddhono, K. \& Kurniawan, A. (2017). Islamic Religious Value in Tradition- al Ceremony of Begalan Banyumasan as Educational Character for Student at Senior High Schools in Central Java. UMRAN: International Journal of Islamic and Civilizational Studies, 4(1-1).https://doi. o r g / 10 . $111113 / \mathrm{u} \mathrm{m}$ ran2017.4n1-1.206.https://jurnalumran.utm.my/index.php/um$\mathrm{ran} / \mathrm{article} / \mathrm{view} / 206$.

Saddhono, K. \& Pramestuti, D. (2018). Sekar Macapat Pocung: Study of Religious Values Based on the Local Wisdom of Javanese Culture. $\mathrm{El} \mathrm{Ha-}$ rakah, 20(1), 15-32. http://dx.doi. org/10.18860/el.v20i1.4724. http://ejournal.uin-malang.ac.id/ index.php/infopub/article/ view/4724.

Setyawan, B. W. \& Saddhono, K. (2018). Ceprotan Performing Art: A Traditional Folkart Based on Urban Legend. Harmonia: Journal of Arts Research and Education, 18(1), 67-73. https://doi.org/10.15294/harmonia.v18i1.9509.https://journal. unnes.ac.id/nju/index.php/harmonia/article/view/9509.

Shiddiq, M. A. \& M. Ishaq S. (2013). Islamic World Unity through Developing Cross-Culture Communication and Religion. Global JAT, 3(1), 7-10. http://www.gjat.my/.

Siddiq, A. (2005). Khittab Nahdiyyah. Surabaya: Khalista and LTN NU of East Java.

Siswayanti, N. (2015). Dakwah Kultural Sunan Sendang Duwur. Buletin AlTuras, 21(1), 1-16.https:// doi. org/10.15408/al-turas.v21i1.3823. http://journal.uinjkt.ac.id/index. $\mathrm{php} /$ al-turats/article/view/3823 
SK Desa No 2/DK/4/414. 107. 07/0/2003

Sofwan, Risdin, et al. (2004). Merumuskan kembali Interelasi Islam-Jawa. Yogyakarta: Gama Media.

Sugiarti, S. (2019). Representation of Culture Ecology in Wisran Hadi's Persiden. Jurnal Litera, 18(1). (https:// doi.org/10.21831/1tr. v18i1.20579) diakses di https:// journal.uny.ac.id/index.php/litera/ article/view/20579

Sujarwoko, S. (2015) Citraan Sufistik Maut dan Islam dalam Puisi Indonesia. Jurnal Litera, 14(2). 239-249. (https://doi.org/10.21831/1tr. v14i2.7201) diakses di https://journal.uny.ac.id/index.php/litera/article/view/7201

Sumardjo. (2000). Filsafat Seni. Bandung: ITB.

Sunyoto, A. (2010). Pengaruh Persia pada Sastra dan Seni Islam Nusantara. Jurnal Al-Qurba, 1(1), 129-139.

Supratno. (2010). Sosiologi Seni Wayang Sasak Lakon Dewi Rengganis dalam Konteks Perubahan Masyarakat di Lombok. Surabaya: Unesa Press.

Suresman, E., \& Suryana, A. T. (2015). Implementasi Dakwah Islam melalui Seni Musik Islami: Studi Deskriptif pada Grup Nasyid Ed- coustic. Tarbawy: Indonesian Journal of Islamic Education, 1(1), 33-47. (http://dx.doi.org/10.17509/t. v2i1.3376) diakses di http://ejournal.upi.edu/index.php/tarbawy/article/view/3376

Sutopo, H. B. (1998). Pengantar Penelitian Kualitatif: Dasar-dasar Teoritis dan Praktis. Surakarta: UNS Press.

Van Dijk, K. (1998). Dakwah and Indigenous Culture: The Dissemination of Islam. Bijdragen tot de Taal-, Landen Volkenkunde, 154 (2), 218-235. h t t p s : / / w w w.jstor.org / stable $/ 27865428$ ? seq=1\#page scan_tab_contents.

Wekke, I. S., \& Sari, Y. R. (2014). Tifa Syawat dan Entitas Dakwah dalam Budaya Islam: Studi Suku Kokoda, Sorong, Papua Barat. Jurnal Thaqãfiyyãt, 13(1), 163-186. http://ejournal.uin-suka.ac.id/adab/thaqafiyyat/article/view/42.

Yahya, M. W. (2007). Strategi Dakwah Islam dalam Pengembangan Seni dan Peradaban. Mediator, 8(2), 221226. https://doi.org/10.29313/mediator.v8i2.1260. diakses di https:// ejournal.unisba.ac.id/index.php/ mediator/article/view/1260. 